\title{
Rapid resolution of Westermarck sign following successful thrombolytic therapy with tenecteplase in acute pulmonary embolism
}

\author{
Nagham Saeed Jafar, ${ }^{1}$ Thottuvelil Narayanan Sunil Roy, ${ }^{1}$ Rajappan Anil Kumar, ${ }^{1}$ \\ Ramanagaram Marigowda Krishna²
}

'Department of Cardiology, Belhoul Speciality Hospital, Dubai, United Arab Emirates ${ }^{2}$ Department of Radiology, Belhoul Speciality Hospital Dubai, United Arab Emirates

\section{Correspondence to} Dr Thottuvelil Narayanan Sunil Roy,

sunilroytn@hotmail.com

\section{DESCRIPTION}

A 35-year-old man presented with syncope followed by progressive shortness of breath of $6 \mathrm{~h}$ duration. The patient was dyspnic and tachypnic at presentation; he has tachycardia with blood pressure of $93 / 51 \mathrm{~mm} \mathrm{Hg}$. There was calf swelling with tenderness in the right leg. ECG showed sinus tachycardia with right axis deviation, right ventricular strain as manifested by $\mathrm{T}$ wave inversion in precordial leads and prominent $S$ wave in lead I with $\mathrm{Q}$ wave and inverted $\mathrm{T}$ wave in lead III $\left(\mathrm{S}_{1}\right.$, $\mathrm{Q}_{3}, \mathrm{~T}_{3}$ pattern). A chest X-ray showed Westermarck sign with focal area of oligaemia in the right lower lung zone with an abrupt cut-off of the right descending pulmonary artery (figure 1).

A bedside echocardiography showed dilated right atrium and ventricle, systolic pulmonary artery pressure was $50 \mathrm{~mm} \mathrm{Hg}$ with moderate tricuspid regurgitation. D-dimer levels were markedly elevated at $5.6 \mathrm{mg} / \mathrm{L}$. An urgent CT angiography of the pulmonary artery showed massive pulmonary embolism (PE) obstructing the right pulmonary artery completely and partially occluding the left pulmonary artery (figure 2). The patient was given thrombolytic therapy with intravenous tenecteplase 7000 units' bolus according to the patient's body weight. Anticoagulation was started with enoxaparin, and warfarin was started $24 \mathrm{~h}$ later. Doppler ultrasonography of the lower limbs showed deep venous thrombosis of the right leg.

A repeat ECG showed disappearance of $S$ wave in lead I and partial reversal of the acute right ventricular strain and this completely normalised after 1 week. Repeat X-ray of the chest within $24 \mathrm{~h}$ of

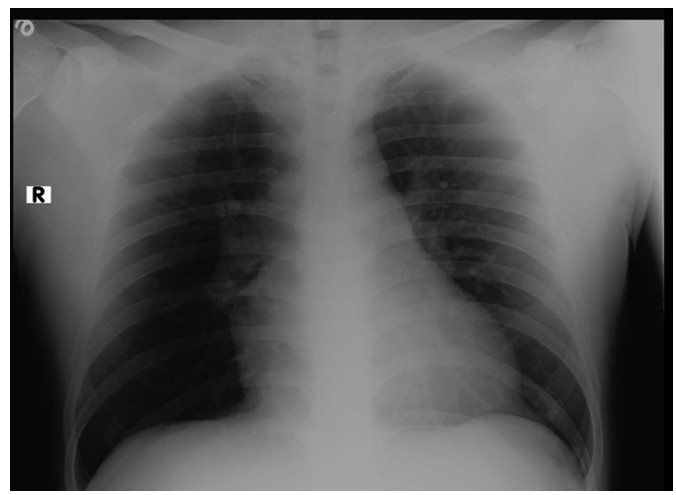

Figure 1 A chest X-ray showing Westermarck sign with focal area of oligaemia in the right lower zone and abrupt cut-off of the right descending pulmonary artery in the lower lobe of the right lung.

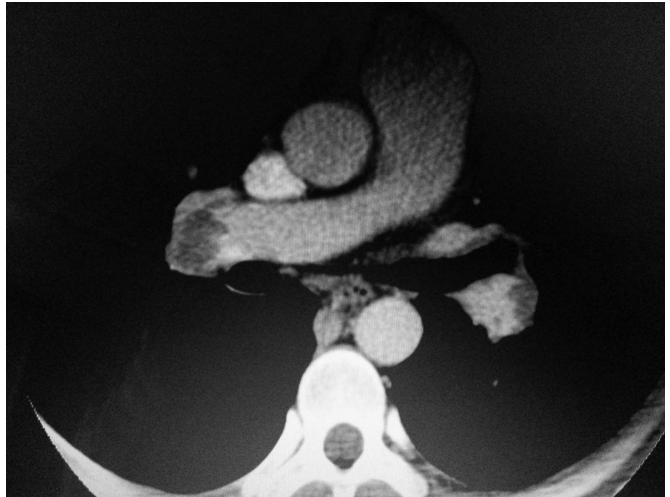

Figure 2 Axial CT pulmonary angiogram illustrating large filling defect completely obstructing the right lower lobe pulmonary artery and partial filling defect in the left pulmonary artery.

thrombolysis showed normalisation of the pulmonary vasculature on the right side (figure 3 ). The patient remained well and was discharged on the fifth day after therapeutic international normalised ratio was obtained. Thrombophilic screening was performed, and the results showed protein $\mathrm{C}$ deficiency. The patient was advised to be on lifelong oral anticoagulation.

The chest X-ray is abnormal in majority of patients with PE. Prospective Investigation of Pulmonary Embolism Diagnosis (PIOPED) study ${ }^{1}$ showed that atelectasis and focal pulmonary parenchymal abnormalities are the most common X-ray findings in PE. The highly specific findings of focal oligaemia or a peripheral wedge-shaped opacity are

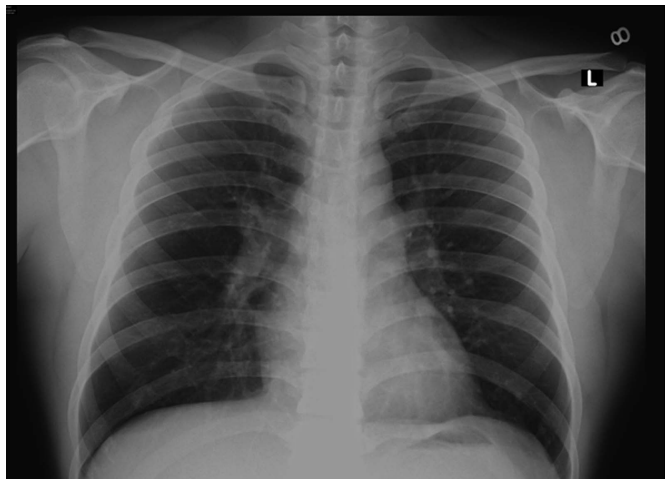

Figure 3 A chest X-ray after $24 \mathrm{~h}$ of thrombolysis showing resolution of the embolus as shown by normalisation of the pulmonary vasculature on the right side. Note also the decrease in size of the heart compared with previous $\mathrm{X}$-ray. 
rare. The Westermarck sign describes a decrease of vascularisation at the periphery of the lungs due to mechanical obstruction or reflex vasoconstriction in PE. ${ }^{2}$ It is seen in $2-5 \%$ of patients with PE. Even though sensitivity is low, this sign is highly specific for the diagnosis of PE.

\section{Learning points}

- The chest X-ray is still helpful in the diagnosis of patients presenting with acute pulmonary embolism (PE).

- The Westermarck sign is a specific radiological sign which may help in early diagnosis of acute PE.

- The Westermarck sign describes focal oligaemia of the lung due to mechanical obstruction or reflex vasoconstriction of the lobar pulmonary artery in PE.
Contributors NSJ and NSR were involved in the conception and drafting of the article and the literature search. RAK the primary physician was involved in the care of the patient and RMK is the radiologist who did the CT pulmonary angiography. RAK and RMK were involved in critically revising the manuscript for its intellectual content. All the four authors have revised the article and approved its intellectual content for its final submission.

Competing interests None.

Patient consent Obtained.

Provenance and peer review Not commissioned; externally peer reviewed.

\section{REFERENCES}

1 Worsley DF, Alavi A, Aronchick JM, et al. Chest radiographic findings in patients with acute pulmonary embolism: observations from the PIOPED study. Radiology 1993;189:133-6.

2 Alagin 0, Gokalp G, Topal U. Signs in chest imaging. Diagn Interv Radiol 2011;17:18-29.

Copyright 2014 BMJ Publishing Group. All rights reserved. For permission to reuse any of this content visit http://group.bmj.com/group/rights-licensing/permissions.

BMJ Case Report Fellows may re-use this article for personal use and teaching without any further permission.

Become a Fellow of BMJ Case Reports today and you can:

- Submit as many cases as you like

- Enjoy fast sympathetic peer review and rapid publication of accepted articles

- Access all the published articles

- Re-use any of the published material for personal use and teaching without further permission

For information on Institutional Fellowships contact consortiasales@bmjgroup.com

Visit casereports.bmj.com for more articles like this and to become a Fellow 